First Peoples Child \& Family Review

An Interdisciplinary Journal Honouring the Voices, Perspectives, and Knowledges of First Peoples through Research, Critical Analyses, Stories, Standpoints and Media Reviews

\title{
Case Study of the Development of the 1998 Tribal State Agreement in Minnesota
}

\section{Evelyn Campbell}

\section{Volume 5, Number 2, 2010}

URI: https://id.erudit.org/iderudit/1068930ar

DOI: https://doi.org/10.7202/1068930ar

See table of contents

Publisher(s)

First Nations Child and Family Caring Society of Canada

ISSN

1708-489X (print)

2293-6610 (digital)

Explore this journal

Cite this article

Campbell, E. (2010). Case Study of the Development of the 1998 Tribal State Agreement in Minnesota. First Peoples Child \& Family Review, 5(2), 45-52. https://doi.org/10.7202/1068930ar

\section{Article abstract}

This paper focuses on a recent qualitative study of the 1998 Indian Child Welfare Tribal State Agreement in Minnesota. The purpose of this study was to document the history of how American Indian women initiated legislative changes at the state level to strengthen the Indian Child Welfare law. This paper will identify the process used by these women and an American Indian workgroup and document the workgroup's recommendations for other states and tribes interested in creating similar agreements.
This document is protected by copyright law. Use of the services of Érudit (including reproduction) is subject to its terms and conditions, which can be viewed online.

https://apropos.erudit.org/en/users/policy-on-use/ 


\title{
First Peoples Child \& Family Review
}

An Interdisciplinary Journal Honoring the Voices, Perspectives and Knowledges of First Peoples through Research, Critical Analyses, Stories, Standpoints and Media Reviews

\section{Case Study of the Development of the 1998 Tribal State Agreement in Minnesota}

\author{
Evelyn Campbella
}

a Evelyn (Evie) Campbell, M.S.W., is an assistant professor in the Department of Social Work at the University of Minnesota Duluth graduate program. Evie is an enrolled member of the Leech Lake Band of Ojibwe and has spent much of her career working with American Indian families. She is contributing author to a recently published book on truancy.

\section{Introduction}

It is important to document North American history from the indigenous peoples' perspective. Oftentimes, American history is written from the Euro-American world view and important information is lost or misunderstood. The author of this article documented how an important piece of legislation that had a major impact on child welfare practice in Minnesota was developed under the guidance of American Indians. This paper is an attempt to capture the voices of the women who took the initiative to work for change on behalf of American Indian children in the State of Minnesota and credit their work. These unsung heroes dedicated much of their lives "saving" their children and their efforts have gone undocumented until now. This article acknowledges those accomplishments and documents their determination to move forward with important legislation which will forever change the lives of many American Indian children who are caught in the system in Minnesota.

Questions or correspondence concerning this article may be addressed to:

Evelyn M. Campbell, MSW

Assistant Professor

University of Minnesota Duluth

230 Bohannon Hall

1207 Ordean Court

Duluth, MN 55812

218.726.8705 (phone)

218.726.7185 (fax)

ecampbel@d.umn.edu

\begin{abstract}
This paper focuses on a recent qualitative study of the 1998 Indian Child Welfare Tribal State Agreement in Minnesota. The purpose of this study was to document the history of how American Indian women initiated legislative changes at the state level to strengthen the Indian Child Welfare law. This paper will identify the process used by these women and an American Indian workgroup and document the workgroup's recommendations for other states and tribes interested in creating similar agreements.

Keywords: Indigenous women, legislative changes, Indian Child Welfare law.
\end{abstract}

\section{Out-of-home Placement for American Indian Children}

Out-of-home placement for American Indian children began during the boarding school era (Red Horse, Martinez, Day, Poupart \& Scharnberg, 2000). As early as the 1600's, Jesuit priests began "civilizing" the American Indian children by providing schools for them where they were taught Christianity (Smith, 2004, p.89). Boarding schools became for formalized from 1869 to 1870, under President Grant (Smith, 2004). At these institutions, children were forced from their homes (Smith, 2004) and told not to speak their language or use their Indian names (Cross, Earle \& Simmons, 2000) or practice their spirituality (Smith, 2004) and were made to change the way they dressed by cutting their hair and expected to act White (Szasz 2005). Rampant cases of sexual, physical and emotional abuse were discovered, but little was done (Smith, 2004).

The intention of the federal government was to teach Christianity to the children in order to "civilize" the population (Cross et al., 2000, p. 3). Both the government and the Christian churches had an interest in the education of American Indian children, believing that these children needed to be Christianized in order to survive in mainstream American society (Cross et al, 
2000). Therefore, federal policies that promoted assimilation were enacted and enforced to end all traces of American Indian language, religion and culture (Morrison, 2010). These assimilation policies included: the Indian Removal Act of 1830 which moved large population of American Indians to urban areas and the termination policies of the 50's and 60's, which resulted in the federal government ending the federal relationship with 61 Indian tribes (Cross et al., 2000). Boarding schools were instituted and used to assimilate American Indian children by taking them away from their tribal communities (Wilkinson, 2005; Morrison, 2010). To "kill the Indian and save the man" was the public policy behind the design and implementation of the Carlisle Indian Industrial School in Pennsylvania in 1879 (Quash-Mah, Stockard, Johnson-Shelton \& Crowly, 2010, p. 896; Redhorse et al., 2000, p. 15; Wilkenson, 2005, p.53). Carlisle, founded by General Richard Pratt, was the first off-reservation boarding school. In an effort to assimilate children General Pratt proposed that the federal government take children away from their families at a young age and return them when they are young adults (Smith, 2004).

\section{Status of American Indian Children in Out- of-Home Placement}

More recently, 12.5 out of every 1,000 Indian children in the United States were in out-of-home placement, compared to 6.9 out of every 1,000 children from all races (Cross et al., 2000, p. 5). In 1974 a national survey by the Association on American Indian Affairs found that about $25 \%$ or more of American Indian children were removed from their families and placed in foster care, group homes, residential schools, other institutions or adopted (Stehno, 1982; Cross et al., 2000; Earle, 2000; Morrison et al., 2010). During 1971 and 1972 in Minnesota, one-fourth of American Indian children under the age of one had been adopted and 90\% were in non-Indian homes (Carver, 1986; Earle, 2000; Redhorse et al., 2000, p. 17). National statistics also reflected this phenomenon (Redhorse et al., 2000, p. 17; Morrison, Fox, Cross \& Paul, 2010). In more recent times, placement rate for American Indian children is higher than for all other children (Quash-Mah et al., 2010).

During the time period that the Tribal State Agreement was created, The Minnesota Department of Human Services (DHS) reported in 1998, that minority children of African American, American Indian, Asian/Pacific Islander or Hispanic race or heritage accounted for $39.6 \%$ of the children in out-of-home placement. In six counties in Minnesota with high American Indian populations, the percentage of minority children in out-ofhome placement ranged from $54.3 \%$ to as high as $85.1 \%$. Four of the counties are rural: Cass $(54.3 \%)$, Beltrami (75.6\%), Clearwater (60.5\%), and Mahnomen (85.1\%). The urban counties include:
Hennepin (71.9\%) and Ramsey (63\%) (Minnesota Department of Human Services, 1998). In Minnesota, 11.1\% of the children in out-of-home placements in 1998 were American Indian, although they only made up $1.8 \%$ of the state's children population (Kuchera, 2001). American Indian children in Minnesota continue to be placed at higher rate, at an earlier age, have more multiple placements and serve longer periods of placement then other groups (Redhorse et al., 2000).

\section{Literature Review}

\section{Indian Child Welfare Act (ICWA)}

The Indian Child Welfare Act became Public Law 95-608 on November 8, 1978. The federal law was designed to protect American Indian families, their communities, and tribes against further disintegration due to the systematic removal of their children by state and county agencies. Evidence introduced to the Senate Subcommittee in Indian Affairs in 1974, illustrated the removal of Indian children from their families was based on discriminatory practices (Sink, 1982). The ICWA is intended to provide protection for the integrity of Indian families by creating and supporting decision-making procedures that include tribal and parent involvement (MacEachron \& Gustavsson, 2005). The law also requires that placement preference is given to American Indian families when an American Indian child is placed (Quash-Mah et al., 2010). Recognizing the importance of protecting and preserving the integrity of American Indian families and their duty to carry this out, Congress enacted legislation that would allow for that. Congress concluded that: "there is no resource that is more vital to the continued existence and integrity of Indian tribes than their children" (Cross, 1986, p. 283). The United States is not the only country that passed laws intended to support and protect the rights of indigenous people by focusing on cultural preservation, self-determination and the transfer of indigenous culture to indigenous children (Roberts, 2002). Unfortunately, many countries do not actively enforce these laws. Boarding schools violated many international human rights laws including the Universal Declaration of Human Rights, The International Covenant on Civil and Political Rights, and The Convention of the Rights of the Child (Smith, 2004). Besides boarding schools, adoption practices also violated human rights laws. The United Nations defines genocide as "forcibly transferring children from one group to another" (Roberts, 2002, p.248). The International Covenant on Civil and Political Rights guarantees indigenous groups the right to enjoy their own culture, practice their own language and use their own language (Roberts, 2002). The Convention of the Rights of Child provides that when the state places children in substitute care efforts should be made to preserve a child's cultural identity (Roberts, 2002). 
The ICWA mandates tribal self-determination policies giving tribes and their courts exclusive jurisdiction and decision making power on adoption and out-of-home placement of their American Indian children residing on their reservation (Cross, et al ,2000; Quash-Mah et al., 2010). The legislation also allows for tribes to develop their own family and child welfare programs (Cross et al., $2000 \&$ Roberts, 2002). However, Congress failed to appropriate any new funding for the implementation of ICWA even though Indian communities could successfully provide comprehensive child welfare and family service programs, if funded accurately (Sink, 1982).

The Indian Child Welfare Act gives tribes jurisdiction over their tribal children. The ICWA law states, "an Indian tribe shall have exclusive jurisdiction to any State over any child custody proceeding involving an Indian child who resides or is domiciled within the reservation, except where jurisdiction is otherwise vested in the State by existing Federal Law. Where the child is a ward of the tribal court, the Indian tribe shall retain exclusive jurisdiction, notwithstanding the residence or domicile of the child" (Indian Child Welfare Act of 1978). An Indian is defined as "any person who is a member of an Indian tribe, including Alaska Native and who is a member of a Regional Corporation" (Indian Child Welfare Act of 1978). Placement preferences for American Indian children is specified for adoption, "in absence of good cause, with extended family, other members of the child's tribe or other Indian families." For foster care or preadoptive placements preference is given to "extended family, a licensed foster home approved by the tribe, a licensed Indian foster home, an institution for children approved by the tribe" (Indian Child Welfare Act of 1978). One of the weaknesses of the ICWA was that it did not "sufficiently address voluntary foster care, pre-adoptive and adoptive placements" (Carver, 1986, p. 353). Prior to the Tribal State Agreement, the State of Minnesota attempted to reinforce ICWA law by adopting its own state law. The following section describes this legislation.

\section{Minnesota Indian Family Preservation Act (MIFPA)}

The MIFPA was passed in 1985 to address the removal of Indian children from their "cultural heritage" due to being placed in non-Indian foster homes (Carver, 1986, p.327). MIFPA strengthen the provisions on foster care by "distinguishing between voluntary foster care placements and involuntary foster care placements and requires social service agencies and private child placing agencies to provide notice to the child's tribe in cases of any potential out-of-home placement (involuntary foster care), voluntary foster care, or any potential pre-adoptive or adoptive placement" (Carver, 1986, p.345). Under state law, there is an early notice provision so that tribes may become involved before the parents rights are terminated (Carver, 1986). The law also requires the agency placing the child to identify "extended family members" when considering placement. (Carver, 1986, p.347).

MIFPA also allows for the immediate return of the child (within 24 hours) to his or her parents whom are placed voluntarily (Carver, 1986). The federal law requires children who are eligible for membership also be the biological child of a member. This limits the number of children to be protected under federal law. The state law differs from the federal law by recognizing Indian children as those eligible for membership giving tribes the authority to define its members (Graves \& Ebbott, 2006). This law shows the State's intent to support American Indian children through the preservation of their culture and the recognition that tribes are best at providing services to their children.

Under MIFPA, a county is required to provide for: 1) foster care maintenance payments, 2) social services that are ordered by a tribal court in conjunction with the placement of an American Indian child, and 3) the financial responsibility for children under tribal court jurisdiction when the county has first contact with the child (Minnesota Department of Human Services, 2004).

\section{Tribal State Agreement}

In Minnesota, the Tribal State Agreement, which was initiated by a small group of American Indian women who started a grassroots movement, was intended to address how American Indian children should be cared for under the requirements of ICWA and the MIFPA. The ICWA, authorizes states and tribes to form an agreement regarding the care and custody of American Indian children, and to determine who has jurisdiction over these children in child custody proceedings (Indian Child Welfare Act of 1978). Agreements may also be revoked with notice to the other party.

The main objective of the Agreement is to set up procedures for county social workers and others to follow the laws (Graves \& Ebbott, 2006). This legislation provided a framework for how to best care for American Indian children when they are placed in the state child protection system. The Tribal State Agreement created valuable safeguards to aid in the cultural considerations of American Indian children when they are removed from home and placed in the care of the state.

The Tribal State Agreement between the Minnesota Indian tribes and the state of Minnesota addresses jurisdiction; defines responsibilities; and the power of tribal courts vs. state courts over the out-of- home placement of American Indian children. The agreement included having a Compliance Review Team monitor county compliance with ICWA and make recommendations on how to work with tribes (Graves \& Ebbott, 2006). The Compliance Review Team was disbanded with 
the 2007 amendment to the Agreement. It was replaced with mediation-style compliance system that has a faster turnaround (T. Yellowhammer, personal communication, October 3, 2008).

The Tribal State Agreement also defines best interest of an American Indian child as a sense of belonging to a family, extended family, clan and Tribe. This concept is enforced through the placement preference outlined in the agreement, having qualified expert witness testimony and participating in "active efforts" (Redhorse et al., 2000, p. 31). Active efforts in the Tribal State Agreement mean active, thorough, careful and culturally appropriate efforts (Redhorse et al., 2000). These efforts must include supportive services to prevent placement of the American Indian child and if the child it placed, to use active efforts to return the child to his or her family as quickly as possible (Redhorse et al., 2000). Active efforts set a higher standard than "reasonable efforts" to preserve and reunify the family.

The Tribal State Agreement specifies that placement preference for children is first with extended family, second, with a foster home licensed by the tribe, third, an Indian home licensed by a non-Indian agency, and fourth placement in a tribally approved institution. For adoption, children are to be placed with extended family first, a member of child's tribe and finally, with another American Indian family unless there is good cause to do otherwise. The Agreement defines "good cause" for not following the placement preference as if the court takes into consideration: 1) the request of the biological parent(s) or child of sufficient age; 2 ) the special needs of the child, or 3) suitable families for placement cannot be found (Tribal State Agreement of 2007).

A qualified expert witness needs to be involved during the placement process or termination of parental right to give testimony that the child will suffer from serious physical or emotional damage if left in the care of her or her parent or Indian custodian. The Agreement has a list of criteria for a qualified expert witness, but they do not supplant the MIFPA which defines qualified expert witness as: a member of the child's tribe who is knowledgeable of tribal customs; a lay expert witness who is knowledgeable of tribal customs within child's tribe; or a professional person who is knowledgeable of tribal customs (Tribal State Agreement of 2007).

The Tribal State Agreement defines best interest of an American Indian child as maintaining ties with his or her tribal community. Through the Tribal State Agreement, the state and tribes agree to collaborate to provide effective services to American Indian children and their families to secure and preserve an American Indian's child sense of belonging to his or her family and tribe (Tribal State Agreement of 2007).
Ten years have passed since Minnesota signed the 1998 Tribal State Agreement. The purpose of this study is historical retrieval for the purpose of: 1) documenting history; 2) acknowledging the accomplishments of American Indian women; 3 ) identifying the process used by the workgroup that initiated the legislation; and 4) documenting the workgroup's recommendations for other states and tribes interested in creating similar agreements. The results of this study could help practitioners working in Indian child welfare understand the importance of the ICWA, MIFPA and the Tribal State Agreement and the rationale for adhering to them.

For First Nations, there past is similar to that of the American Indians. Assimilation policies that forced children into boarding schools also existed in Canada (Thomlison \& Foote, 1987). Research completed in the 1980's indicated that at least "one half of the children in care are Indian or Metis children” (p. 134). The status of Aboriginal children by 1983 was overrepresented in the child welfare system across Canada (Bennett, Blackstock \& De La Rhonde, 2005). In 1984, The Child Family Services Act was amended to recognize the unique cultural needs of First Nations' people and to provide for services that take into consideration "Native culture, traditions, and the concept of extended family" (p.54). Having a document similar to the Tribal State Agreement could potentially allow First Nations' to establish procedures and safeguards for child protection services working with Indigenous children. It would hold provincial governments accountable for more culturally appropriate treatment of Indigenous children in Canada. Bennett et al., (2005) suggests that the next step for First Nations is self-governance. For First Nations to develop an agreement similar with the federal government to the Tribal State Agreement in the United States could be a step forward in self-determination, and meeting the needs of their families, particularly their children.

\section{Methodology}

\section{Research Methodology}

The methodology used for this study was a historical retrieval, case study. It included structured, in-depth interviews with five American Indians who shared a personal recollection of what they experienced during the creation of the Agreement. The narrative approach to research allows for the "systematic study of personal experience and meanings; how events have been constructed by active subjects" (Pooyak \& Gomez, 2009, p. 13). This is important for the researcher because participants can reflect on their own experience, share knowledge and vision, without their responses having to fit into a specific category. It also looks at "authoring the stories of ordinary people tell" ( $\mathrm{p}$. 13). Morrison et al., (2010) refers to this as a "story" (p. 108) and argues that a story is a part of "tribal tradition and worldview and 
are a natural form of research in a tribal community" (p. 108). This study obtained University of Minnesota IRB approval.

A purposive snowball sampling was used to select the sample population. In this study, the Minnesota Department of Human Services provided a list of approximately 15 names of individuals who were members of the original workgroup. These individuals were directors or coordinators of tribal human service agencies and American Indian urban programs. After reviewing the list from the state, the researcher worked in collaboration with one of the workgroup members to identify other participants who could be contacted. The author of this paper was able to locate five participants. After participants were located a letter was sent asking for their help in understanding the experiences of drafting the 1998 Tribal State Agreement. They were told the information gathered will aid in a better understanding of the intent and outcomes of the Agreement and that the results would be shared with Indian Tribes, tribal workers, and those practicing in Indian child welfare as well as, The Minnesota Indian Child Welfare Advisory Council to further their understanding of the process of drafting the Agreement. The letter stated: "To participate in this process, please find attached a list of questions that I will be asking in an interview with you. I will be contacting you in the next few weeks to set up a date and time to conduct the interview either by phone or in-person. Your names will be kept confidential. Your input will provide valuable information and your participation will be greatly appreciated."

Several follow-up phone calls were made to set up appointments for the interview. Telephone interviews followed. All but one of the participants contacted were American Indian women who were employed and over 50 years of age. One of the participants was retired. During the time of the drafting of the agreement the women were either working for a Minnesota tribe or contracted to work for them.

The participants were called and asked standard questions about how they got involved in the process and what they remember. After the initial inquiries they continued telling researcher their story about what they remember about the process. They spoke about the purpose of the agreement, recalled the process itself, and gave suggestions on what others who are interested in doing the same type of initiative should do. The snowball technique was used during interviews with the five individuals. This method involved the sample being created "from a series of referrals made within a group of people who know one another" (Streeton, Cooke \& Campbell, 2004, p. 37). More specifically, they were asked "who else do you remember was active in the workgroup and where do you think they are working now or could be located."

\section{Data Collection}

The study reported in this paper used structured interviews as the method of data collection. The first set of five questions was intended to discover what members of the workgroup hoped to accomplished when working on the Agreement, what the foundation for creating the Agreement was and what was happening in Indian Country at the time to cause them to draft this agreement. The second set of four questions focused on the process and what the process was like for the workgroup when drafting the agreement. The third set of three questions addressed recommendations the workgroup would make to others interested in creating their own agreement or a similar document.

Questions were developed to use in a structured interview with respondents. One of the workgroup members who is now considered an expert in Indian child welfare issues due to her many years of experience, leadership position, and national recognition assisted in the development of the following twelve questions.

\section{Motivation for Developing the Tribal State Agreement}

1. According to the $1998 \mathrm{Tribal} /$ State Agreement (Agreement), the foundation of the Agreement was based on the continued existence of the tribes by keeping American Indian children connected to their tribal community. Is that correct? If so, how was that done?

2. Was the original intentions (goals and objectives) of the 1998 Tribal/State Agreement carried out? What were they?

3. The 1998 Tribal/State Agreement purpose was to strengthen ICWA and MIFPA, how did that happen?

4. Do we need both the 1998 Tribal/State Agreement and MIFPA? Why?

5. Does the 1998 Tribal/State Agreement still meet the goals of family preservation? Why or Why not?

\section{Process}

1. Could you describe the process of drafting the agreement? Cumbersome? Lengthy? Wasteful? Productive? And Why?

2. How was the workgroup formed and did most or all those involved in drafting the agreement agree with the outcomes? Was their group consensus?

3. What was the state's relationship with the workgroup? Supportive? Combative? 
4. What strengths and challenges did you encounter with the process?

\section{Recommendations}

1. How would other states begin this process?

2. What recommendations would you give them?

3. Is there anything that would have been done differently?

\section{Data Analysis/Results/Findings}

The final results were tabulated under three subheadings: 1) motivation, 2) process, and recommendations. Themes were identified under each subheading using a frequency count; how often two or more respondents gave the same or similar answer.

\section{Motivation}

The theme that emerged for the first subheading is the common belief that county workers, judges and attorneys as well as, those working with American Indian children were not following ICWA. One respondent commented that, "Noncompliance was occurring."

\section{Process}

Two themes emerged for the second subheading. The first theme was that the process used to create the document was "lengthy and cumbersome." The second theme was concern about the relationship with DHS. Workgroup members believed that the state was more focused on their relationship with counties than the concern tribes had over their children. One workgroup member commented that they were not treated as equals and struggled with the state over certain issues.

\section{Recommendations}

The theme that emerged from the third subheading was that the workgroup members agreed that those that are going to engage in this type of work be prepared, patient and informed. They argued that this was a good starting point for them that resulted in a useful mechanism for holding counties accountable and provide a guide for more appropriate treatment of American Indian children and families in the State of Minnesota.

\section{Discussion}

The first set of questions asked the workgroup why the legislation had to be created in the first place and if the intention of the agreement had been carried out. The first set of responses focused on the fact that counties were not doing enough to implement the Indian Child Welfare Act, as a result the respondents had hoped that a State Tribal Agreement would strengthen ICWA and stopped Minnesota tribes from losing children because of non-Indian agencies practice policies.

The 1998 Tribal State Agreement had been created after tribal child protection workers realized that counties were not complying with the ICWA and the MIFPA and further, many social workers did not know the purpose or history of the ICWA. During this time, out-of-home placement for American Indian children was higher than any other racial group. A workgroup participant reported that grandmothers on the reservations were worried when they realized the tribes children were disappearing and there were few children left in the community. She also said that counties did little to implement the practice of "active efforts" when working with American Indian children. When members of the workgroup convened on this issue, they worked with state officials to create the Tribal State Agreement. The working group was able to locate the only other Tribal State Agreement, which was the State of Washington. They used the document from Washington to guide them in their efforts to develop a Tribal State Agreement in Minnesota. Clearly having another document to use as a prototype provided a helpful framework for forming the Tribal State Agreement in Minnesota.

The tribal workers, mostly women, came together and confronted the Minnesota Department of Human Services to see what could be done to force counties to comply. These women formed a workgroup to address this concern and went to St. Paul, the state capitol, and met with DHS staff to figure out what could be done about the continued disregard of ICWA. One workgroup member responded that they were not treated as equals and struggled with the state over certain issues. For example, the tribes tried to change passive language in social service manuals to make it stronger. Unfortunately, there are still words such as, "may," "shall" or "encourages counties to..." in the Minnesota social service manual. Words such as "will" or "required to" are not in the manual. Workgroup members believed that the state was more focused on their relationship with counties than on the concern tribes had over their children.

The second set of questions was written to discover what the process was like. The workgroup was able to reach general conclusions about the process itself, as well as, give examples what had occurred. When participants in the workgroup discussed the process they all agreed it was lengthy and that they did not get much support from the county. Some of the DHS staff consisted of American Indians who took on the positions of liaison to the tribes to help simplify the process and reduce any confusion. The workgroup members reported the process was confusing, frustrating and time-consuming. Without the diligent efforts of this workgroup it is unlikely that, little if anything, would have happened to address the counties and their disregard for ICWA or the lack of recognition of tribal sovereignty. 
The final set of questions asked the workgroup what recommendations they would give to others interested in creating their own agreement. It is unfortunate that tribes had to spend their time, money and energies on something that should have already been happening, that is compliance with ICWA. However, the members of the workgroup believed that it was a necessary process and they all agreed that they would not have changed anything about the process. They acknowledged they were pioneers in this process and only had one other model to follow. One participant recommended having an enforcement clause to ensure compliance.

Most, members of the workgroup agreed that it is important to go in to meetings prepared when attempting to initiate state legislation and to be patient about the process and informed about current laws and policies about child welfare issues.

\section{Limitation}

One limitation of this study is the small sample size. However, this is the first step in documenting the process used by the workgroup beginning in 1993. Minutes to these workgroup meetings were documented by a tribal agency secretary, but ended up destroyed in a fire at the Minnesota Chippewa Tribe headquarters. Other limitation included some participants of the workgroup were unable to be located and one participant declined to be interviewed.

\section{Conclusion}

Recent national statistics show that out-of-home placement rates for American Indian and First Nations children are disproportionately higher than for any other group of children. The lack of compliance with current laws and a lack of cultural understanding contribute to this problem. One way a group of Minnesota Indian women addressed this problem was by developing a piece of legislation to enforce ICWA. This article in an attempt to document the history of a small group of tribal women who took action during the 1990's. Their stories show on way Indian tribes across the United States and Canada can address the problem of the lack of compliance with current legislation. All of the Minnesota workgroup members agreed that they were pioneers in creating this Agreement and wanted something that would be useful to child welfare practitioners and others working with Indigenous children. They felt the Agreement established procedures for following ICWA and had safeguards for working with American Indian children. It was a good starting point that resulted in a useful mechanism for holding counties accountable and encouraging appropriate treatment of American Indian children and families in the State of Minnesota.
In summary, further research is needed about the personal experience of the workgroup. Additional questions for this workgroup and DHS would be: 1) What was happening at the time in Indian Country at the time of this Agreement? 2) Why out-of-home placement was high for American Indian children? 3) Why were the children taken out of their homes? and 4) What did the court reports document?

Other research questions that are important include: 5) How can DHS improve relations with Indian tribes to match county responsiveness? 6) What was the perspective of DHS on the process of developing the Tribal State Agreement? 7) Has compliance improved with this agreement? 8) Why were revision made in 2007 and what were they? 9) Why is there no longer a compliance team and how is the change to a mediation compliance system working? Finally, more workgroup members could be interviewed to gain their perspective and provide a more complete history.

What makes this project unique is the historical significance of the 1998 Tribal State Agreement. The State of Minnesota and the Minnesota Indian Tribes were at the forefront of creating a grounding breaking document. There has been little documentation of significant policy issues around the Indian Child Welfare Act and the 1998 Tribal State Agreement as well as the importance of having a Tribal State Agreement. This research is a step toward providing the much needed documentation.

\section{References}

Bennett, M., Blackstock, C., \& De La Rhonde, R. (2005). A Literature Review and Annotated Bibliography on Aspects of Aboriginal Child Welfare in Canada. Retrieved November 12, 2010, from http://www.cecw-ceph. $\mathrm{ca} /$ publications/998.

Carver, K. (1986). The 1985 Minnesota Indian Family Preservation Act: Claiming a Cultural Identity. Law \& Inequity, 4: 327-354.

Cross, Terry A. (1986). Drawing on Cultural Tradition in Indian Child Welfare. Social Casework: The Journal of Contemporary Human Services, 67: 283-289.

Cross, Terry A., Earle, Kathleen A., \& Simmons, David. (2000). Child Abuse and Neglect in Indian Country: Policy Issues. Families in Society: The Journal of Contemporary Human Services, 81(1): 49-58.

Earle, K. (2000, December). Child Abuse and Neglect: An Examination of American Indian Data. Retrieved November 15, 2010, from http://www. nicwa.org/research/02.Child_Abuse.pdf.

Graves, Kathy D., \& Ebbott, Elizabeth (2006). Indians in Minnesota. Minneapolis, MN: University of Minnesota Press. Indian Child Welfare Act, 25 U.S.C. sections 1901 to 1963 (1978). Retrieved November 22, 2010, from http://www.icwlc.org/docs/1-icwa-1091.pdf.

Kuchera, Steve. (2001, November 4). Learning Cultural Differences. Duluth News Tribune, pp. 1C-2C.

MacEachron, A., \& Gustavsson, N., (2005). Contemporary Policy Challenges for Indian Child Welfare. Journal of Poverty, 9(2):43-61. 


\section{Case Study of the Development of the 1998 Tribal State Agreement in Minnesota}

Minnesota Department of Human Services. Bulletin \#04-68-10, November 24, 2004. Retrieved November 22, 2010, from http://www.icwlc.org/ docs/8-icwa-dhs-bulletin-04-68-10_id_038808.pdf.

Minnesota Department of Human Services. (1998). Children in Out-Of-Home Care Report: County Data on Race or Heritage of Children, 1998. Retrieved November 22, 2010, from http://archive.leg.state.mn.us/docs/ pre2003/mandated/000369.pdf.

Minnesota Indian Family Preservation Act, Minn. Stat. sections 260.751 to 160.835 (1985). Retrieved November 22, 2010, from http://www. icwlc.org/docs/3-icwa-mifpa.pdf.

Minnesota Tribal/State Indian Child Welfare Agreement (February 22, 2007). Retrieved November 22, 2010, from http://www.icwlc.org/docs/9icwa_2007_tribal_state_agreement_dhs-5022-eng-2-07.pdf.

Minnesota Department of Human Services, Social Service Manual, Xiii-3500 to 3687 (September 29, 1998). Retrieved November 22,2010, from http:// www.icwlc.org/docs/6-icwa_minnesota_social_service_manual.pdf.

Morrison, C., Fox, K., Cross, T., \& Paul, R. (Jan/Feb 2010). Permanency Through Wabanaki Eyes: A Narrative Perspective from The Peoples Who Live Where the Sun Rises. Child Welfare, 89(1): 103-123.

Pooyak, S., \& Gomez, Y. (2009). Using the Narrative Approach to Understanding the Frontline Practices and Experiences of Aboriginal and Non-Aboriginal Child Protection Workers. First Peoples Child \& Family Review, 4(2): 10-17.

Quash-Mah, S., Stockard, J., Johnson-Shelton, D., \& Crowley, R. (June 2010). Fulfilling the Hope of ICWA: The role of community context. Children and Youth Services Review, 32(6), p. 896-901.

Red Horse, John G., \& Martinez, C., Day, P., Poupart, J., \& Scharnberg, D. (2000). Family Preservation: Concepts in American Indian Communities. Retrieved June 20, 2006, from http://www.nicwa.org/resources/ catalog/research/2000/01.FamilyPreservation.pdf

Roberts, Dorothy. (2002). Shattered Bonds: The Color of Child Welfare. New York, NY: Basic Civitas Books.

Sink, David. (1982). Making the Indian Child Welfare Act Work: Missing Social and Governmental Linkages. Phylon, 43: 360-367.

Smith, Andrea. (2004, Winter). Boarding school abuses, human rights, and reparation. Social Justice. Retrieved November 4, 2010, from http://find. galegroup.com.libpdb.d.umn.edu:2048/gtx/infomark.do?contentSetIAC-Documents\&type $=$ retrieve $\&$ tabID $=T 002 \&$ prodId $=A O N E \&$ doc $\mathrm{Id}=\mathrm{A} 136652504 \&$ source $=$ gale $\&$ srcprod $=\mathrm{A}$.

Streeton, R., Cooke, M., \& Campbell, J. (2004). Researching the researchers: Using the snowballing technique. Nurse Researcher, 12(1): 35-37.

Stehno, Stephanie M. (1982). Differential Treatment of Minority Children in Services Systems. Social Work, 27(1):39-45.

Szasaz, M. (2005). "I knew how to be moderate. And I know how to obey."; The Commonality of American Indian Boarding School Experiences, 1750s-1920s. American Indian Culture and Research Journal, 29(4): 75-94.

Thomlison, R., \& Foote, C. (Summer, 1987). Child Welfare in Canada. Child and Adolescent Social Work, 4(2): 123-143.

Wilkenson, C., (2005). Blood Struggle: The Rise of Modern Nations. W.W. Norton \& Co., New York, N.Y.

Yellowhammer, Terry, personal communication, October 3, 2008. 